\title{
EFFECT OF REGULATED DEFICIT IRRIGATION AND BORON RATES ON SUGAR BEET PRODUCTIVITY IN NEWLY RECLAIMED SOILS
}

\author{
A.M. Osman (1), K.M. Agami(2), H.M. El-Sharnoby(3) and A.Kh. Abdelhalim(1) \\ (1) Water Requirements and Field Irrigation Research Dept.; Soils, Water and Environment. \\ Res. Inst., ARC, Egypt \\ (2) Department of Agronomy and Agricultural Practices; Sugar Crops Res., Inst.; ARC, \\ Egypt \\ (3) Department of Agricultural Physiology and Chemistry, Sugar Crops Res., Inst.; ARC, \\ Egypt
}

Received: May 18, 2019

Accepted: Jun. 27,2019

\begin{abstract}
A field experiment was conducted at $\mathrm{Km} 71$ West Nubaria, Alex./ Cairo desert Road, El-Behiera Government, Egypt, during two successive winter seasons, $2017 / 18$ and 2018/ 19. The objective was to study the effect of five regulated deficit irrigation treatments $\left[I_{1}=\right.$ No stress at all physiological stages, $I_{2}=$ skip irrigation at the beginning of development stage (60 days from sowing), $I_{3}=$ skip irrigation during development stage ( 90 days from sowing), $I_{4}=$ skip irrigation at mid season (120 days from sowing) and $I_{5}=$ skip irrigation at late season (150 days from sowing)], and four rates of boron fertilizer applied as boric acid, $\left[B_{1}=\right.$ Without $B$ (control), $B_{2}=0.5 \mathrm{~kg} \mathrm{~B} / \mathrm{fed}, B_{3}=0.75$

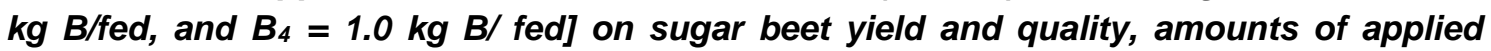
irrigation water and water utilization efficiency. The results showed that irrigation treatments and boron rates had a significant effect on root, shoot and sugar yields. The obtained results indicated that the reductions in root yield were 9.55, 6.43, 5.58 and 0.84 t/fed, while for sugar yields were 1.89, 1.34, 1.22 and 0.10 t/fed for $I_{2}, I_{3}, I_{4}$ and $I_{5}$, respectively compared to no stress treatment. The results showed that the combined effect of irrigation treatment $I_{1}$ (no stress at all stages) and boron fertilizer rate $B_{2}(0.5 \mathrm{~kg} \mathrm{~B} / \mathrm{fed})$ gave the highest average values of root yield (35.041 t/fed) and sugar yield (6.315 t/fed) over the two seasons. On the other hand the average amount of applied irrigation values were 2145, 1929, 1822, 1858 and $1895 \mathrm{~m}^{3} / \mathrm{fed}$ for the $I_{1}, I_{2}, I_{3}, I_{4}$ and $I_{5}$ irrigation treatments, respectively. Likewise, the highest average water utilization efficiency for sugar beet root and sugar yields of $16.523 \mathrm{~kg}$ root $/ \mathrm{m}^{3}$ water applied and $2.951 \mathrm{~kg} \mathrm{sugar} / \mathrm{m}^{3}$ water applied were obtained with the irrigation treatment $I_{5}$ (skip irrigation at late season stage) and boron fertilizer $B_{3}(0.75 \mathrm{~kg} \mathrm{B/fed})$ over two seasons. It could be maintained herein that the no stress irrigation water $I_{1}$, with $0.75 \mathrm{~kg} \mathrm{B/fed} \mathrm{treatment} \mathrm{achieved} \mathrm{the} \mathrm{highest} \mathrm{yield} \mathrm{of}$ sugar beet (root and sugar) of the availability of sufficient irrigation water. Otherwise it is suggested to follow the irrigation treatment $I_{5}$ (no irrigation at late season) and applying boron fertilizer at rate of $0.75 \mathrm{~kg} \mathrm{B/fed} \mathrm{obtain} \mathrm{high} \mathrm{sugar} \mathrm{beet} \mathrm{yields.}$
\end{abstract}

Key words: Sugar beet - water stress - Boron - sugar yield - Water utilization

\section{INTRODUCTION}

Sugar beet (Beta vulgaris L.) is one of the important winter crops in Egypt. It is well adapted to Egyptian environment especially in the newly reclaimed calcareous and sandy soils. The crop has essential position in winter crop rotation, not only in fertile soils but also in poor sandy, saline-alkaline and calcareous soils. Also, it consumes less water than sugar cane. Water use efficiency for producing one kilogram of sugar needs 
about 1.4 and $4.0 \mathrm{~m}^{3}$ water by sugar beet and sugar cane, respectively (Quda, 2001). The need for water by different plant species depend on how much moisture stress, they are able to tolerate at any particular stage of growth. English (1990) stated that, controlled deficit irrigation proved to be an efficient tool for further research. Under water shortage conditions, this technique relates the drought stress on the plant at a given phonological stage to possible decreases in the production or quality of the crop harvested. Doorenbos and Pruitt (1975) described the physiological stages of sugar beet as: initial (25-30 days), crop development (35-60 days), mid- season (50-70 days), late season (30-50 days), and ripening (till harvesting). Yonts et al. (1999) showed that limited irrigation under furrow or sprinkler systems resulted in decrease in root and sugar yields by $\mathbf{3 . 8}$ t/ha and $0.6 \mathrm{t} / \mathrm{ha}$, respectively compared to the full irrigation treatment. Emara et al. (2000) showed that the average seasonal water applied for sugar beet was ranged between 2720 to $1699 \mathrm{~m}^{3}$ / fed. (64.8- 40.4 $\mathrm{cm})$ depending upon stress status. Ibrahim et al. (2002) showed that the highest values of sugar beet root yield (34.95 and $30.20 \mathrm{t} / \mathrm{fed}$ ) and sugar yield (5.00 and $3.18 \mathrm{t} / \mathrm{fed}$ ) were obtained under drought period of 6 weeks before harvesting in the first and second seasons, respectively in clay soil.

Boron is, by far, the most important trace element needed by sugar beet because the yield and quality of roots is very depressed without an adequate supply of it (Cooke and Scott, 1993; and Allen et al. 2007). Adequate boron (B) nutrition is critical for high yields and quality of crops. Boron increases the rate of transport of sugars (which are produced by photosynthesis in mature plant leaves) to actively growing parts and in developing fruits. Hellal et al. (2009) showed that all boron doses $(0,25,50$ and $100 \mathrm{ppm}$ ) as boric acid foliar spray found to give a significant increase in the shoot and root yields of sugar beet as compared to the untreated plants. Application of $\mathbf{5 0}$ ppm B was the best for achieving maximum fresh shoot and root yields as compared to other boron treatments. Positive effect of Boron may be due to its role in cell elongation and turgidity, while in case of boron deficiency plant leaves were reported to be smaller, stiff and thick (Brown and Hu, 1996).

This work was carried out to investigate the effect of five regulated deficit irrigation treatments and four boron fertilizer rates on sugar beet yield, quality, amounts of applied water and water utilization efficiency in the newly reclaimed loamy sand soils of West Nubaria region.

\section{MATERIALS AND METHODS}

A field experiment was carried out during the two winter seasons of 2017/18 and 2018/19 at km 71 West Nubaria, Alexandria/Cairo Desert Road, El-Behiera Government, Egypt. Soil samples were collected before sowing from two depths of $0-30$ and $30-60 \mathrm{~cm}$ to determine soil physical (particle sizes, textural class, and bulk density) and chemical (EC, pH, cations and anions) properties (Page et al., 1982), and some soil hydro-physical (field capacity, wilting point, and available soil moisture) parameters. The values of analysis are given in Tables 1 and 2.

\section{Experimental design and tested variables:}

The experiment was laid out in a split plot design with three replicates. The main plots were assigned to the deficit irrigation treatments, while four boron rates as boric acid $\left(\mathrm{H}_{3} \mathrm{BO}_{3}, 17 \%\right)$ were randomly distributed in the sub-plots. The tested treatments were as follows: 
Effect of regulated deficit irrigation and boron rates on sugar beet productivity....

Table (1): Some chemical and physical properties of soil at the experimental site.

\begin{tabular}{|c|c|c|c|c|c|c|c|c|c|}
\hline \multirow{3}{*}{$\begin{array}{l}\text { Soil } \\
\text { depth } \\
\text { (cm) }\end{array}$} & \multirow{3}{*}{$\begin{array}{c}\text { EC } \\
(\mathrm{dS} / \mathrm{m})\end{array}$} & \multirow{3}{*}{ pH } & \multicolumn{7}{|c|}{ Chemical parameters } \\
\hline & & & \multicolumn{4}{|c|}{ Cations (meq/L) } & \multicolumn{3}{|c|}{ Anions (meq/L) } \\
\hline & & & $\mathrm{Ca}$ & $\mathrm{Mg}$ & $\mathrm{Na}$ & $\mathrm{K}$ & $\mathrm{HCO}_{3}$ & $\mathrm{Cl}$ & $\mathrm{SO}_{4}$ \\
\hline $0-30$ & 1.14 & 7.35 & 3.10 & 2.30 & 4.65 & 1.20 & 2.72 & 7.09 & 0.98 \\
\hline $30-60$ & 1.04 & 7.15 & 3.20 & 2.40 & 4.55 & 1.30 & 2.70 & 7.29 & 0.80 \\
\hline \multirow{2}{*}{$\begin{array}{l}\text { Soil } \\
\text { depth } \\
\text { (cm) }\end{array}$} & \multicolumn{9}{|c|}{ Physical parameters } \\
\hline & \multicolumn{2}{|c|}{ Sand (\%) } & Silt (\%) & \multicolumn{2}{|c|}{ Clay (\%) } & \multicolumn{2}{|r|}{$\begin{array}{l}\text { Textural } \\
\text { class }\end{array}$} & \multicolumn{2}{|c|}{$\begin{array}{l}\text { Bulk density } \\
\left(\mathrm{g} / \mathrm{cm}^{3}\right)\end{array}$} \\
\hline $0-30$ & \multicolumn{2}{|c|}{87.41} & 6.87 & \multicolumn{2}{|r|}{5.72} & \multicolumn{2}{|r|}{ loamy Sand } & \multicolumn{2}{|c|}{1.43} \\
\hline $30-60$ & \multicolumn{2}{|c|}{86.29} & 7.93 & \multicolumn{2}{|r|}{5.78} & \multicolumn{2}{|r|}{ loamy Sand } & \multicolumn{2}{|c|}{1.59} \\
\hline
\end{tabular}

Table (2): Field capacity (FC), Wilting point (WP), and available soil moisture (ASM) values of the soil at experimental site.

\begin{tabular}{|l|c|c|c|}
\hline Soil depth (cm) & FC (\%) & WP (\%) & ASM (\%) \\
\hline $0-30$ & 17.60 & 9.56 & 8.04 \\
\hline $30-60$ & 15.65 & 8.51 & 7.14 \\
\hline Average & 16.63 & 9.04 & 7.59 \\
\hline
\end{tabular}

Deficit irrigation (main plots):

$I_{1}=$ No stress at all physiological stages.

$I_{2}=$ No irrigation at the beginning of development stage (60 days from sowing).

$I_{3}=$ No irrigation at the development stage (90 days from sowing).

$\mathrm{I}_{4}=$ No irrigation at mid season (120 days from sowing).

$I_{5}=$ No irrigation at late season (150 days from sowing).

Boron rates (sub-plots):

$B_{1}=$ without (control)

$B_{2}=0.5 \mathrm{~kg} \mathrm{~B} / \mathrm{fed}$

$B_{3}=0.75 \mathrm{~kg} \mathrm{~B} / \mathrm{fed}$

$B_{4}=1.0 \mathrm{~kg} \mathrm{~B} / \mathrm{fed}$

Solutions were prepared for use by dissolving appropriate amount of $\left(\mathrm{H}_{3} \mathrm{BO}_{3}\right)$ in $400 \mathrm{~L}$ of deionized water and were sprayed in two equal doses after 50 and 70 days from sowing.

\section{Cultural practices:}

The area of experimental plot was 21 $m^{2}(1 / 200 \mathrm{fed})$. Each plot included six ridges, $\mathbf{0 . 5}$ meter apart and $\mathbf{7 . 0}$ meters in length. During land preparation, calcium super phosphate $\left(15.5 \% \mathrm{P}_{2} \mathrm{O}_{5}\right)$ at the rate of $100 \mathrm{~kg} / \mathrm{fed}$, potassium sulfate $(48 \%$ $\mathrm{K}_{2} \mathrm{O}$ ) at the rate of $50 \mathrm{~kg} / \mathrm{fed}$ were incorporated into the soil. Nitrogen fertilizer in the form of Urea $(46 \% \mathrm{~N})$ as side dressing at the rate of $100 \mathrm{~kg} \mathrm{~N} / \mathrm{fed}$, was applied in two equal doses, half after thinning (before the first irrigation) and the other half before the second irrigation.

Sugar beet balls were hand sown, 3- 5 balls par hill on one side of the ridge on the $13^{\text {th }}$ and $21^{\text {st }}$ of September and plants were harvested after 6 months at 2017/18 and 2018/19 seasons, respectively. Plants were thinned at the fourth leaf growth stage to obtain one plant/hill. The common agricultural practices for growing sugar beet according to the recommendations of Ministry of Agriculture were followed, except for the studied factors. At the harvest time the plants were uprooted and topped, then the following data were collected: 
A.M. Osman, et al.,

A- Sugar beet yield and its components:

I- Yield parameters:

1- Root yield (t/fed).

2- Shoot yield (t/fed).

3- Sugar yield (t/fed). It was calculate as follows:

Sugar yield $=$

$$
\text { Root yield }\left(\frac{t}{f e d}\right) X \text { sucrose (\%) }
$$

II- Quality characters:

1- Sucrose percentage.

2- Total soluble solids (TSS, \%). It was measured in fresh roots juice by using Hand Refractometer according to Me Ginnis (1982).

3- Purity percentage.

B- Soil water relations:

1- Potential crop evapotranspiration $\left(E T_{p}\right)$ :

Potential crop evapotranspiration $\left(E T_{p}\right)$ values for the two growing seasons were calculated by using the weather data from weather station established at Nubaria Research Station, using CROPWAT model (Smith, 1991) based on FAO, Penman- Monteith method. The equation is given as:

ETo $=$

$\frac{0.408 \Delta(R n-G)+\gamma[900 /(T+273)] U_{2}\left(e_{s}-e_{a}\right)}{\Delta+\gamma\left(1+0.34 U_{2}\right)}$

where:

$\mathrm{Rn}=$ net radiation $\left(\mathrm{MJ} \mathrm{m}^{-2} \mathrm{~d}^{-1}\right)$

$G=$ soil heat flux $\left(\mathrm{MJ} \mathrm{m}^{-2} \mathrm{~d}^{-1}\right)$

$\Delta=$ slope of vapor pressure and temperature curve $\left(\mathrm{kPa}^{\circ} \mathrm{C}^{-1}\right)$

$\Gamma=$ psychrometric constant $\left(\mathrm{kPa}^{\circ} \mathrm{C}^{-1}\right)$

$\mathrm{U}_{2}=$ wind speed at $2 \mathrm{~m}$ height $\left(\mathrm{ms}^{-1}\right)$

$\mathbf{e}_{\mathrm{s}}-\mathbf{e}_{\mathrm{a}}=$ vapor pressure deficit $(\mathrm{kPa})$

$\mathrm{T}=$ mean daily air temperature at $\mathbf{2} \mathrm{m}$ height

$\left({ }^{\circ} \mathrm{C}\right)$

The crop evapotranspiration (ETc) values were calculated according to following equation:

$$
E T c=E T P X K c
$$

where:

$E_{c}=$ Crop evapotranspiration $(\mathrm{mm} /$ day $)$.

$E T_{p}=$ Potential evapotranspiration (mm/day).

$K_{c}=$ Crop coefficient. The values for sugar beet crop are presented in Table 3 .

2- Amount of applied irrigation water (AIW):

The amount of applied irrigation water was measured by a flow meter and was calculated according to the following equation:

$A I W=\frac{E T C}{E a(1-L R)}$

where:

AIW = Applied irrigation water depth (mm/day).

$E_{a}=$ Irrigation efficiency $(70 \%$ for surface irrigation system under experimental conditions).

$L R=$ Leaching requirements $(10 \%$ of applied irrigation water).

3- Water utilization efficiency (WUE $\mathrm{kg} / \mathrm{m}^{3}$ ):

Water utilization efficiency values were calculated according to Doorenbos and Pruitt (1975) as follows:

1- WUE for roots yield $\left(\mathrm{kg} / \mathrm{m}^{3}\right)=$ $\frac{\text { Roots yields in } \mathrm{Kg} / \mathrm{fed}}{\text { Water applied in } \mathrm{m3} / \mathrm{fed}}$

2- WUE for sugar yield $\left(\mathrm{kg} / \mathrm{m}^{3}\right)=$ Sugar yields in $\mathrm{Kg} / \mathrm{fed}$

Water applied in $\mathrm{m} 3 / \mathrm{fed}$

\section{Statistical analysis:}

Data of the two seasons were combined and analyzed by "MSTAT" computer software package and a least significant difference (L.S.D) method was used to test the differences between treatments. Means at $5 \%$ probability level were compared. Statistical analysis was done according to Steel and Torrie (1981). 


\section{RESULTS AND DISCUSSION}

A- Sugar beet yield and yield components:

I- Yield characters (roots, shoot and sugar yields):

The 2017/18 and 2018/19 combined analysis of the effect of irrigation treatments and boron rates on root, shoot and sugar yields (t/fed) is presented in Table 4. The results showed that irrigation treatments and boron fertilizer rates had a significant effect on root, shoot and sugar yields. The highest mean values of 27.252 , 7.969, and $4.764 \mathrm{t} / \mathrm{fed}$ over the two seasons for root, shoot, and sugar yields, respectively were obtained as affected by the $I_{1}$ treatment (no stress at all physiological stages), which may be ascribed to that plants did not suffer from water stress at any stage during the growing season. The obtained data revealed that water stress during late season stage did not significantly reduce root, shoot, and sugar yields. While, the same traits were significantly reduced when the plants were subjected to water stress during beginning, development and mid-season stages as compared to no stress treatment.

The 2-year average recorded in root yields reached $9.55,6.43,5.58$ and 0.84 t/fed, for shoot yields were 5.06, 3.97, 1.18 and $1.12 \mathrm{t} / \mathrm{fed}$, and for sugar yields were $1.89,1.34,1.22$ and $0.10 \mathrm{t} / \mathrm{fed}$ affected by $I_{2}, I_{3}, I_{4}$, and $I_{5}$ treatments, respectively as compared to non stress $\left(I_{1}\right)$ treatment. Results indicated that, the application of
$I_{1}$ (no stress) and $I_{5}$ (stress at late season stage) will not significantly affect root, shoot, and sugar yields under experimental conditions. The obtained results may be due to the effect of moisture stress on vegetative growth stage of sugar beet plants. The results agreed with those reported by Ibrahim et al. (2002) and Emara et al. (2000). Also, Wittenmayer and Schiling (1998) mentioned that, as sugar beet is subjected to water stress, the root yield decreased. Dunham (1993) found that early water stress during beginning of development stage decreased root yield more than the late stress.

In regard to the effect of boron fertilizer rates on root, shoot and sugar yields (Table 4). The results indicated that increasing boron rates $0.5,0.75$, and 1.0 $\mathrm{kg} \mathrm{B/fed,} \mathrm{increased} \mathrm{root} \mathrm{yields} \mathrm{by} 4.449$, 6.270 and $3.908 \mathrm{t} / \mathrm{fed}$, shoot yields by $1.595,2.176$ and $1.315 \mathrm{t} / \mathrm{fed}$, and sugar yields by $0.958,1.207$ and $0.746 \mathrm{t} / \mathrm{fed}$, respectively as compared with the control treatment $\left(B_{1}\right)$. Results indicated that, spraying sugar beet crop with $0.75 \mathrm{~kg}$ B/fed gave the highest values of root, shoot and sugar yields. The effect of boron application may be due to the important functions of boron in stimulating plant metabolism, development and growth (Abido, 2012). Also, sugar beet yield reduction at the high level of boron is attributed to the toxicity influence of this element (Kristek et al., 2006).

Table (3): Sugar beet crop coefficient values (Allen et al. 1998).

\begin{tabular}{|l|c|c|}
\hline Stage & Period (day) & Crop Coefficient $\left(\mathrm{K}_{\mathrm{c}}\right)$ \\
\hline Initial stage & $30-35$ & 0.35 \\
\hline Development & $45-60$ & 1.20 \\
\hline Mid-season & $90-70$ & 0.70 \\
\hline Late season & $15-40$ & 0.50 \\
\hline
\end{tabular}


A.M. Osman, et al.,

Table (4): The effect of the deficit irrigation and boron rates treatments on root, shoot, and sugar yields of sugar beet crop.

\begin{tabular}{|c|c|c|c|}
\hline Treatments & Root Yield (t/ fed) & Shoot Yield ( $t /$ fed) & Sugar Yield ( $t /$ fed) \\
\hline \multicolumn{4}{|c|}{ Irrigation } \\
\hline$I_{1}$ & $27.252 \mathrm{a}$ & $7.969 \mathrm{a}$ & $4.764 \mathrm{a}$ \\
\hline$I_{2}$ & $17.697 \mathrm{~b}$ & $2.909 \quad \mathrm{~b}$ & $2.877 \quad b$ \\
\hline$I_{3}$ & $20.825 \mathrm{~b}$ & $4.002 \mathrm{~b}$ & $3.422 \mathrm{~b}$ \\
\hline $\mathrm{I}_{4}$ & $21.674 \quad b$ & $6.790 \mathrm{a}$ & $3.546 \mathrm{~b}$ \\
\hline$I_{5}$ & 26.417 a & $6.853 \mathrm{a}$ & $4.660 \mathrm{a}$ \\
\hline L.S.D 0.05 & 3.592 & 1.424 & 0.625 \\
\hline \multicolumn{4}{|c|}{ Boron } \\
\hline $\mathrm{B}_{1}$ & $19.116 \mathrm{~b}$ & $4.433 \mathrm{~b}$ & $3.126 \mathrm{~b}$ \\
\hline$B_{2}$ & 23.565 a & $6.028 \mathrm{a}$ & $4.084 \mathrm{a}$ \\
\hline $\mathrm{B}_{3}$ & $25.386 \mathrm{a}$ & $6.609 a$ & $4.333 \mathrm{a}$ \\
\hline $\mathrm{B}_{4}$ & $23.024 \mathrm{a}$ & $5.748 a$ & $3.872 \mathrm{a}$ \\
\hline L.S.D 0.05 & 2.678 & 1.217 & 0.447 \\
\hline \multicolumn{4}{|c|}{ Interaction } \\
\hline$I \times B$ & $* * *$ & $* * *$ & $* * *$ \\
\hline
\end{tabular}

The interaction effect of deficit irrigation and boron fertilizer rates treatments on root, shoot and sugar yields ( $t / f e d)$ is presented in Table (5). Results indicated that, irrigation $I_{1}$ (no stress at all stages) and boron treatment $B_{2}(0.5 \mathrm{~kg} \mathrm{~B} / \mathrm{fed})$ bring about the highest value of root yield (35.041 t/fed) and sugar yield $(6.315 \mathrm{t} / \mathrm{fed})$. While, the lowest values of root (10.883 t/fed) and sugar yield (1.688 t/fed) were achieved with irrigation treatment $I_{2}$ (no irrigation at beginning development stage) and boron treatment $B_{1}$ (without boron fertilizer). Also, no irrigation at late season stage $\left(I_{5}\right)$ and boron fertilizer rate of $0.5 \mathrm{~kg} \mathrm{B/fed,}$ achieved the highest value of shoot yield (10.207 t/fed), while the lowest value of $2.197 \mathrm{t} / \mathrm{fed}$ was obtained with irrigation $I_{2}$ (no irrigation at beginning development stage) and boron fertilizer treatment $B_{2}$ (0.5 kg B/fed).

II- Quality characters (sucrose, total soluble solids, and purity percentages):

The effect of irrigation and boron rates treatments on sucrose, total soluble solids (TSS) and purity percentages is presented in Table (6). The results manifested that irrigation treatments and boron fertilizers rates had a significant effect on sucrose percentage and total soluble solids (TSS, \%). However, no effect of the irrigation and boron fertilizer rates treatments was observed, on purity percentage. The highest mean values of sucrose percentage $(17.71 \%)$ and total 
soluble solids (23.50\%) were induced with the irrigation treatment $I_{5}$ (no irrigation at late season stage), while the highest mean value of purity $\mathbf{( 7 6 . 3 \% )}$ was obtained from irrigation treatment $I_{2}$. The results in Table 6 , revealed also that spraying sugar beet plants by $0.75 \mathrm{~kg} \mathrm{B/fed} \mathrm{caused} \mathrm{the} \mathrm{highest}$ values of sucrose percentage (17.14\%) and total soluble solids content (22.93\%). The highest value of purity percentage (75.4\%) was occurred with boron fertilizer treatment $B_{4}(1.0 \mathrm{~kg} \mathrm{~B} / \mathrm{fed})$. These findings were in line with that found by Hellal et al. (2009), who stated that sucrose\% increased with increasing boron doses.

Table (5): Interaction effect of deficit irrigation and boron rates treatments on root, shoot, and sugar yields of sugar beet crop.

\begin{tabular}{|c|c|c|c|c|}
\hline Irrigation & Boron & Root Yield ( $t /$ fed) & Shoot Yield (t/ fed) & Sugar Yield ( $t / \mathrm{fed}$ ) \\
\hline \multirow{4}{*}{$\mathbf{I}_{1}$} & $\mathbf{B}_{1}$ & 18.928 & 7.474 & 3.217 \\
\hline & $\mathbf{B}_{2}$ & 35.041 & 6.238 & 6.315 \\
\hline & $\mathrm{B}_{3}$ & 29.120 & 9.159 & 5.218 \\
\hline & $\mathrm{B}_{4}$ & 25.918 & 9.005 & 4.304 \\
\hline \multirow{4}{*}{$\mathbf{I}_{2}$} & $\mathrm{~B}_{1}$ & 10.883 & 2.759 & 1.688 \\
\hline & $\mathrm{B}_{2}$ & 22.534 & 2.197 & 3.753 \\
\hline & $\mathbf{B}_{3}$ & 18.048 & 4.037 & 2.988 \\
\hline & $\mathbf{B}_{4}$ & 19.323 & 2.643 & 3.078 \\
\hline \multirow{4}{*}{$I_{3}$} & $B_{1}$ & 15.633 & 4.212 & 2.409 \\
\hline & $\mathrm{B}_{2}$ & 15.113 & 3.348 & 2.303 \\
\hline & $\mathrm{B}_{3}$ & 26.670 & 4.678 & 4.507 \\
\hline & $\mathrm{B}_{4}$ & 25.883 & 3.768 & 4.468 \\
\hline \multirow{4}{*}{$I_{4}$} & $\mathrm{~B}_{1}$ & 25.429 & 5.020 & 4.165 \\
\hline & $B_{2}$ & 22.517 & 8.149 & 3.668 \\
\hline & $\mathbf{B}_{3}$ & 21.785 & 6.941 & 3.360 \\
\hline & $\mathbf{B}_{4}$ & 16.963 & 7.048 & 2.991 \\
\hline \multirow{4}{*}{$I_{5}$} & $\mathrm{~B}_{1}$ & 24.705 & 2.701 & 4.150 \\
\hline & $B_{2}$ & 22.622 & 10.207 & 4.381 \\
\hline & $B_{3}$ & 31.308 & 8.230 & 5.591 \\
\hline & $\mathbf{B}_{4}$ & 27.034 & 6.275 & 4.518 \\
\hline \multicolumn{2}{|l|}{ L.S.D 0.05} & 4.975 & 2.261 & 0.830 \\
\hline
\end{tabular}


A.M. Osman, et al.,

Table (6): Quality characters of Sugar beet crop as affected by the deficit irrigation and boron application .

\begin{tabular}{|c|c|c|c|}
\hline Treatments & Sucrose (\%) & TSS (\%) & Purity (\%) \\
\hline \multicolumn{4}{|c|}{ Irrigation } \\
\hline $\mathbf{I}_{1}$ & $17.60 \mathrm{a}$ & $23.17 \mathrm{a}$ & $76.2 \mathrm{a}$ \\
\hline$I_{2}$ & $16.23 \mathrm{~b}$ & $21.50 \mathrm{~b}$ & $76.3 \mathrm{a}$ \\
\hline$I_{3}$ & $16.24 \mathrm{~b}$ & $22.17 \mathrm{~b}$ & $73.6 \mathrm{a}$ \\
\hline$I_{4}$ & $16.47 \mathrm{~b}$ & $22.33 \mathrm{~b}$ & $73.8 \mathrm{a}$ \\
\hline$I_{5}$ & $17.71 \mathrm{a}$ & $23.50 \mathrm{a}$ & $75.4 \mathrm{a}$ \\
\hline L.S.D 0.05 & 0.65 & 0.75 & N.S. \\
\hline \multicolumn{4}{|c|}{ Boron } \\
\hline$B_{1}$ & $16.24 \mathrm{~b}$ & $21.73 \mathrm{~b}$ & $74.7 \mathrm{a}$ \\
\hline$B_{2}$ & 17.12 a & $22.87 a$ & $75.3 \mathrm{a}$ \\
\hline $\mathrm{B}_{3}$ & $17.14 \mathrm{a}$ & $22.93 \mathrm{a}$ & $74.7 \mathrm{a}$ \\
\hline $\mathbf{B}_{4}$ & $16.89 \mathrm{a}$ & $22.60 \mathrm{a}$ & $75.4 \mathrm{a}$ \\
\hline L.S.D 0.05 & 0.59 & 0.75 & N.S \\
\hline \multicolumn{4}{|c|}{ Interaction } \\
\hline$I \times B$ & $* * *$ & $* * *$ & $* * *$ \\
\hline
\end{tabular}

The interaction effect of irrigation treatments and boron fertilizers rates on sucrose, total soluble solids, and purity percentages are presented in Table 7. Results pointed out that irrigation treatment $I_{5}$ (no irrigation at late season stage) and boron fertilizer treatment $B_{2}$ $(0.5 \mathrm{~kg} \mathrm{~B} / \mathrm{fed})$ scored the highest values of sucrose percentage $(19.20 \%)$ and purity percentage (83.3\%). While, the highest value of total soluble solids content $(24.67 \%)$ was obtained from irrigation treatment $\left(I_{5}\right)$ and boron fertilizer rate $\left(B_{3}\right)$. The obtained results are in harmony with with those reported by Almin and Asgharipour (2012), who stated that spraying boron with concentrations of $8 \%$ (0.70 kg B/ha) and 12\% (1.22 kg B/ha) significantly increased yield compared with the control. Also, sucrose concentration promoted significantly with the increase of boron concentration.

\section{B- Soil water relations:}

1- Potential evapotranspiration $\left(E T_{p}\right)$ :

Potential evapotranspiration (ETp) values calculated by FAO PenmanMontieth methods, using CROPWAT model for the two growing seasons are presented in Table 8. The seasonal ETp values were 53.14 and $50.92 \mathrm{~cm}$ in 2017/18 and 2018/19 growing seasons, respectively.

\section{2- Amount of applied irrigation water (AIW):}

The depths, amounts, and mean applied irrigation water by surface irrigation system to the sugar beet crop according to the irrigation treatments during the two growing seasons are 
presented in Table 9. Results indicated that the AIW values were 2166, 1927, 1828, 1933 and $1989 \mathrm{~m}^{3} /$ fed for $I_{1}, I_{2}, I_{3}, I_{4}$ and $I_{5}$ irrigation treatments, respectively during the first season. The values were 2123 , $1932,1816,1784$ and $1800 \mathrm{~m}^{3} / \mathrm{fed}$. for the same respective treatments during the second season. The overall average of amount of applied irrigation water (AIW) values were 2145, 1929, 1822, 1858 and $1895 \mathrm{~m}^{3} /$ fed for the $I_{1}, I_{2}, I_{3}, I_{4}$ and $I_{5}$ irrigation treatments, respectively. The applied water for $I_{2}, I_{3}, I_{4}$ and $I_{5}$ irrigation treatments were 10.01, 15.02, 13.35 and $11.64 \%$, respectively less than $I_{1}$ treatment. The obtained results cleared that amount of applied water decreased by decreasing the number of irrigations according to the selected growth stage. The obtained results agreed with those of Doorenbos and Kassam (1979), Eid et al. (1987) and Abdel-Nasser et al. (2014).

Table (7): Interaction effects of deficit irrigation and boron rates treatments on quality characters of sugar beet crop.

\begin{tabular}{|c|c|c|c|c|}
\hline Irrigation & Boron & Sucrose (\%) & TSS (\%) & Purity (\%) \\
\hline \multirow{4}{*}{$\mathbf{I}_{1}$} & $\mathbf{B}_{1}$ & 17.07 & 22.67 & 75.3 \\
\hline & $\mathbf{B}_{2}$ & 18.13 & 22.67 & 80.0 \\
\hline & $\mathbf{B}_{3}$ & 18.67 & 22.67 & 82.3 \\
\hline & $\mathrm{B}_{4}$ & 16.53 & 22.67 & 67.0 \\
\hline \multirow{4}{*}{$I_{2}$} & $\mathbf{B}_{1}$ & 15.63 & 21.33 & 73.3 \\
\hline & $\mathbf{B}_{2}$ & 16.67 & 22.67 & 75.3 \\
\hline & $\mathbf{B}_{3}$ & 16.57 & 22.67 & 73.0 \\
\hline & $\mathbf{B}_{4}$ & 16.03 & 19.33 & 83.3 \\
\hline \multirow{8}{*}{$I_{3}$} & $\mathbf{B}_{1}$ & 15.37 & 21.67 & 70.7 \\
\hline & $\mathrm{B}_{2}$ & 15.27 & 23.67 & 65.0 \\
\hline & $\mathbf{B}_{3}$ & 16.90 & 21.67 & 78.0 \\
\hline & $\mathbf{B}_{4}$ & 17.43 & 21.67 & 80.7 \\
\hline & & 16.33 & 21.33 & 76.7 \\
\hline & $B_{2}$ & 16.33 & 22.33 & 73.0 \\
\hline & $B_{3}$ & 15.53 & 23.00 & 67.3 \\
\hline & $\mathrm{B}_{4}$ & 16.67 & 22.67 & 78.0 \\
\hline \multirow{4}{*}{$I_{5}$} & $\mathrm{~B}_{1}$ & 16.80 & 21.67 & 77.3 \\
\hline & $\mathrm{B}_{2}$ & 19.20 & 23.00 & 83.3 \\
\hline & $\mathbf{B}_{3}$ & 18.03 & 24.67 & 73.0 \\
\hline & $\mathbf{B}_{4}$ & 16.80 & 24.67 & 68.0 \\
\hline \multicolumn{2}{|l|}{ L.S.D ${ }_{0.05}$} & 1.09 & 1.40 & 6.2 \\
\hline
\end{tabular}


A.M. Osman, et al.,

Table (8): Potential evapotranspiration (ETp) values during the two growing seasons.

\begin{tabular}{|l|c|c|c|c|}
\hline \multirow{2}{*}{ Month } & \multicolumn{2}{|c|}{$2017 / 18$} & \multicolumn{2}{c|}{$2018 / 19$} \\
\cline { 2 - 5 } & ETp (mm/day) & mm/Month & ETp (mm/day) & mm/month \\
\hline Sep. & 4.34 & 73.78 & 4.18 & 37.62 \\
\hline Oct. & 3.11 & 96.41 & 3.09 & 95.79 \\
\hline Nov. & 1.95 & 58.50 & 1.92 & 57.60 \\
\hline Dec. & 1.34 & 41.54 & 1.25 & 38.75 \\
\hline Jan. & 1.25 & 38.75 & 2.28 & 70.68 \\
\hline Feb. & 1.96 & 56.84 & 2.70 & 75.60 \\
\hline Mar. & 2.86 & 88.66 & 3.81 & 118.11 \\
\hline Apr. & 4.05 & 76.95 & 5.01 & 15.03 \\
\hline Total (mm) & & 531.43 & & 509.18 \\
\hline
\end{tabular}

Table (9): Depths, amounts, and means of applied water $\left(\mathrm{mm} \& \mathrm{~m}^{3} / \mathrm{fed}\right)$ of different irrigation treatments for sugar beet crop during 2017/18 and 2018/19 growing seasons.

\begin{tabular}{|l|c|c|c|c|c|c|c|c|c|c|}
\hline \multirow{2}{*}{$\begin{array}{l}\text { Days } \\
\text { from } \\
\text { sowing }\end{array}$} & \multicolumn{7}{|c|}{$\mathrm{I}_{1}$} & \multicolumn{2}{|c|}{$\mathrm{I}_{2}$} & \multicolumn{2}{c|}{$\mathrm{I}_{3}$} & \multicolumn{2}{c|}{$\mathrm{I}_{4}$} & \multicolumn{2}{c|}{ I $^{\prime}$} \\
\cline { 2 - 11 } & $2017 / 18$ & $2018 / 19$ & $2017 / 18$ & $2018 / 19$ & $2017 / 18$ & $2018 / 19$ & $2017 / 18$ & $2018 / 19$ & $2017 / 18$ & $2018 / 19$ \\
\hline Sowing & 189.50 & 145.90 & 189.5 & 145.90 & 189.5 & 145.90 & 189.5 & 145.90 & 189.5 & 145.90 \\
\hline 40 & 91.34 & 83.86 & 91.34 & 83.86 & 91.34 & 83.86 & 91.34 & 83.86 & 91.34 & 83.86 \\
\hline 60 & 56.90 & 45.26 & - & - & 56.90 & 45.26 & 56.90 & 45.26 & 56.90 & 45.26 \\
\hline 90 & 80.43 & 72.93 & 80.43 & 72.93 & - & - & 80.43 & 72.93 & 80.43 & 72.93 \\
\hline 120 & 55.45 & 80.71 & 55.45 & 80.71 & 55.45 & 80.71 & - & - & 55.45 & 80.71 \\
\hline 150 & 42.05 & 76.71 & 42.05 & 76.71 & 42.05 & 76.71 & 42.05 & 76.71 & - & - \\
\hline $\begin{array}{l}\text { Total } \\
(\mathrm{mm})\end{array}$ & 515.67 & 505.37 & 458.77 & 460.11 & 435.24 & 432.44 & 460.22 & 424.66 & 473.62 & 428.66 \\
\hline $\mathrm{m}^{3} / \mathrm{fed}$ & 2166 & 2123 & 1927 & 1932 & 1828 & 1816 & 1933 & 1784 & 1989 & 1800 \\
\hline Mean & 2145 & 1929 & 1822 & 1858 & 1895 \\
\hline
\end{tabular}


3- Water utilization efficiency (WUE, $\left.\mathrm{kg} / \mathrm{m}^{3}\right)$ :

The effect of irrigation treatments and boron fertilizer rates on average water utilization efficiency as $\mathrm{kg}$ roots and sugar yields per cubic meter of applied water is presented in Table 10. Results indicated the highest WUE root and sugar yields values of $13.164 \mathrm{~kg}$ root $/ \mathrm{m}^{3}$ water and $2.460 \mathrm{~kg} \mathrm{sugar} / \mathrm{m}^{3}$ water were obtained for irrigation treatment $I_{5}$ (no irrigation at late season stage). Also, the highest WUE root and sugar yield values of $13.164 \mathrm{~kg}$ root $/ \mathrm{m}^{3}$ water and $2.243 \mathrm{~kg} \mathrm{sugar} / \mathrm{m}^{3}$ water were occurred due to boron fertilizer treatment $\mathrm{B}_{3}(0.75 \mathrm{~kg} \mathrm{~B} / \mathrm{fed})$. The results coincided with those reported by Doorenbos and Pruitt (1975) and Osman et al. (2005).
The interaction effect of irrigation treatments and boron fertilizer rates on average water utilization efficiency values for root and sugar yields is presented in Table 11. The results showed that the highest WUE root and sugar yields values of $16.523 \mathrm{~kg} \mathrm{root} / \mathrm{m}^{3}$ water and $2.951 \mathrm{~kg}$ sugar $/ \mathrm{m}^{3}$ water were obtained from irrigation treatments $I_{5}$ (no irrigation at late season stage) and boron fertilizer treatment $B_{3}(0.75 \mathrm{~kg} \mathrm{~B} / \mathrm{fed})$. Similar results were founed by Emara et al. (2000), who reported that the highest water utilization efficiency was $14 \mathrm{~kg} / \mathrm{m}^{3}$ which was accompanied with drought stress at late season growth stage.

Table (10): Average water utilization efficiency values for root and sugar yields as affected by deficit irrigation treatments and boron rates of sugar beet crop.

\begin{tabular}{|l|c|c|}
\hline Treatments & WUE of root yield $\left(\mathrm{kg} / \mathrm{m}^{3}\right)$ & WUE of sugar yield $\left(\mathrm{kg} / \mathrm{m}^{3}\right)$ \\
\hline$I_{1}$ & 12.709 & 2.222 \\
\hline$I_{2}$ & 9.258 & 1.491 \\
\hline$I_{3}$ & 11.429 & 1.878 \\
\hline$I_{4}$ & 11.665 & 1.909 \\
\hline$I_{5}$ & 13.942 & 2.460 \\
\hline L.S.D 0.05 & 1.643 & 0.289 \\
\hline$B_{1}$ & 9.954 & 1.626 \\
\hline$B_{2}$ & 12.074 & 2.088 \\
\hline$B_{3}$ & 13.164 & 2.243 \\
\hline$B_{4}$ & 12.010 & 2.010 \\
\hline L.S.D 0.05 & 1.337 & 0.225 \\
\hline I X B & $* * *$ & $* * *$ \\
\hline
\end{tabular}


A.M. Osman, et al.,

Table (11): The interaction effect of deficit irrigation and boron fertilizer rate treatments on average water utilization efficiency values for root and sugar yields of sugar beet crop.

\begin{tabular}{|c|c|c|c|}
\hline Irrigation & Boron & $\begin{array}{c}\text { WUE of root yields } \\
\left(\mathrm{kg} / \mathrm{m}^{3}\right)\end{array}$ & WUE of sugar yields $\left(\mathrm{kg} / \mathrm{m}^{3}\right)$ \\
\hline \multirow{4}{*}{$\mathbf{I}_{1}$} & $\mathbf{B}_{1}$ & 8.827 & 1.500 \\
\hline & $\mathbf{B}_{2}$ & 16.341 & 2.945 \\
\hline & $\mathbf{B}_{3}$ & 13.580 & 2.434 \\
\hline & $\mathbf{B}_{4}$ & 12.087 & 2.008 \\
\hline \multirow{4}{*}{$\mathbf{I}_{2}$} & $\mathrm{~B}_{1}$ & 5.640 & 0.875 \\
\hline & $\mathbf{B}_{2}$ & 11.678 & 1.945 \\
\hline & $\mathbf{B}_{3}$ & 9.353 & 1.548 \\
\hline & $\mathbf{B}_{4}$ & 10.359 & 1.595 \\
\hline \multirow{4}{*}{$I_{3}$} & $\mathbf{B}_{1}$ & 8.579 & 1.322 \\
\hline & $B_{2}$ & 8.294 & 1.264 \\
\hline & $\mathbf{B}_{3}$ & 14.637 & 2.474 \\
\hline & $\mathbf{B}_{4}$ & 14.205 & 2.452 \\
\hline & $\mathbf{B}_{1}$ & 13.687 & 2.242 \\
\hline & $B_{2}$ & 12.119 & 1.975 \\
\hline & $\mathbf{B}_{3}$ & 11.726 & 1.808 \\
\hline & $\mathbf{B}_{4}$ & 9.130 & 1.610 \\
\hline \multirow{4}{*}{$I_{5}$} & $\mathbf{B}_{1}$ & 13.038 & 2.190 \\
\hline & $\mathbf{B}_{2}$ & 11.939 & 2.312 \\
\hline & $\mathbf{B}_{3}$ & 16.523 & 2.951 \\
\hline & $\mathbf{B}_{4}$ & 14.268 & 2.385 \\
\hline \multicolumn{2}{|l|}{ L.S.D ${ }_{0.05}$} & 2.989 & 0.503 \\
\hline
\end{tabular}

\section{Conclusions}

From the obtained results it could be concluded that:

1- Sugar beet yield and yield components were significantly reduced when the plants were subjected to water stress during beginning, development and mid season stages compared with no stress treatment.
2- The boron fertilizer rates had a significant effect on root, shoot and sugar yields.

3- The results showed that, irrigation treatment $I_{1}$ (no stress at all stages) and boron fertilizer treatment $B_{2}(0.5 \mathrm{~kg}$ $B / f e d)$ gave the highest values of root yield (35.041 t/fed) and sugar yield (6.315 t/fed). 
4- Irrigation treatments and boron fertilizer rates had a significant effect on sucrose percentage and total soluble solids.

5- Average amount of applied irrigation values were 2149, 1929, 1822, 1858 and $1895 \mathrm{~m}^{3} / \mathrm{fed}$ for $\mathrm{I}_{1}$ (no stress at all stages), $I_{2}$ (stress at beginning development stage), $I_{3}$ (stress at development), $\mathrm{I}_{4}$ (stress at midseason) and $I_{5}$ (stress at late season) irrigation treatments, respectively.

6- The highest water utilization efficiency for root and sugar yields were (16.523 $\mathrm{kg}$ root $/ \mathrm{m}^{3}$ water applied) and (2.951 kg sugar $/ \mathrm{m}^{3}$ water applied) were obtained from irrigation treatment $I_{5}$ (no irrigation at late season stage) and boron fertilizer $B_{3}(0.75 \mathrm{~kg} \mathrm{~B} / \mathrm{fed})$.

\section{REFERENCE}

Abdel-Nasser, G., Kh.T. Ben Abdalla, A.M. Osman, I. Goher and K. Agami (2014). Response of sugar beet yield to deficit irrigation under drip irrigation system. J. Adv. Agric. Res. 19 (3): 442- 458.

Abido, W.A.E. (2012). Sugar beet productivity as affected by foliar spraying with methanol and boron. International J. of Agric. Sci., 4 (7): 287 292.

Allen, R., I.A.B. Pereira and M. Smith (1998). Crop evapotranspiration guide lines for computing crop water requirement, Irr. Sci., 56: 116- 127.

Allen, V., Barker, J. David and E. Pibeam (2007). Handbook of plant nutrition. (Books in Soils, plant and the environment). Boron by Umesh Gupta. 2007: 241- 278.

Almin, M. and M. Asgharipaur (2012). Effect of time and concentration of boron foliar application on yield and quality of sugar beet. AmericanEurasian. J. Agric. B. Environ. Sci., 12 (4): 448.

Brown, P. H. and H. Hu (1996). Phloem mobility of boron in species dependent. Evidence for phloem mobility in sorbitol.

Cooke, D.A. and R.K. Scott (1993). The sugar beet crop. Chapman and Hall London, PP. 262- 265.

Doorenbos, J. and W.O. Pruitt (1975). Crop water requirement $F A O$ Irrigation and Drainage Paper. No. 24. Revised 1977, Rome, Italy.

Doorenbos, I. and A. Kassam (1979). Yield response to water by F.A.O Irrigation and Drainage Paper No. 33, Rome, Italy.

Dunham, R.M. (1993). The sugar beet crop: Science in to Poctice. Water use and irrigation. Chapman \& Hall, PP. 279- 309.

Eid, H.M., N.G. Ainer and M. Metwally (1987). Estimation of irrigation and temperature needs for the new land in Egypt. Conf. of Agric. Sci., an Food Deficiency Overcoming through Autonomous Ette in Egypt, June 22, 1994, 4: 907- 914.

Emara, T.K., M.A.M. Ibrahim and M.A. Sherif (2000). Critical beet growth stages in relation to crop water needs in North Nile Delta. Alex. Sci., Exchange. 21 (1): 41- 53.

English, M. (1990). Deficit irrigation, Analytical fram work. J. ir. Drain. Eng. 116 (1): 399- 412.

Hellal, F.A., A.S. Taalab and A.M. Safaa (2009). Influence of nitrogen and boron nutrient balance and sugar beet yield growth in calcareous soil. Ozean J. of Applied Sci., 2 (1): 2009.

Ibrahim, M. M., M.R. Khalifa, H.A. Koriem, F.I. Zein and E.H. Omer (2002). Yield and quality of quality of sugar beet crop as affected by mid- and lateseason drought and potassium fertilization at North Nile Delta, Egypt, J. Soil Sci. 42 (1): 87- 102.

Kristek, A., B. Stojic and S. Kristek (2006). Effect of the foliar boron fertilization on sugar beet root yield and quality. Agric. Sci., and Professional Rev. 12 (1). 
Me Ginnis, R.A. (1982). Beet sugar technology. $3^{\text {rd }}$ ed. Sugar beet development foundation Fort Collins $855 \mathrm{pp}$.

Osman, A.M., H.E. Khalifa, M.M. Attia and M.A. Sayed (2005). Effect of drip irrigation treatments on sugar beet yield and quality and some water relations in sandy soils. The $13^{\text {th }}$ Conference of Misr Society of Agric. Eng., 14- 15 December, 2005: 774- 787.

Quda, Sohier M. M. (2001). Response of sugar beet to $N$ and $K$ fertilizers levels under sandy soil conditions. Zagazig $\mathrm{J}$. Agric. Res., 28 (2): 275- 297.

Page, A.L., R.H. Miller and D.R. Keeny (1982). Methods of soil analysis. Amer. Soc. Agric. Inc. Madison, USA.

Smith, M. (1991). CROPWAT a Computer Program for irrigation planning an management. FAO Irrigation and Drainage Paper No. 46. Rom, 126 P.

Steel, R.G.D. and J.H. Torrie (1981). Principles of statistics a biometrical approach. $2^{\text {nd }}$ ed. By McGraw-Hills International Book Company, Singapore, 633p.

Wittenmayer L. and G. Schiling (1998). Behavior of sugar beet plants (Beta vulgaris L. Sp. Vulgaris Var. altissima Doell,) under conditions of changing water supply Abscisic acid as indicator. J. Sgron. Crop Sci. 180 (4): 65- 72.

Yonts, C.D., K.L. Palm and D.L. Reichert (1999). Late season irrigation management for optimum sugar beet production. ASAEI CSAE- SCGR Annual Int. Meet. 18- 21 July, Toronto, Ontario, Canada, P. 10. 
تأثير النقص المنظم للرى ومعدلات البورون على إنتاجية بنجر السكر بالأراضى حديثة الإستصلاح

عبد السلام مرغنى عثمان(") ، كمال محمد عجمى(r) ، حسام محمد الثرنوبى(") ،

عبدالهادي خميس عبدالحليم (1)

(1) قسم بحوث المقتنات المائيه والرى الحقلى - معهذ بحوث الأراضى والمياه والبيئه- مركز البحوث الزراعيه- مصر

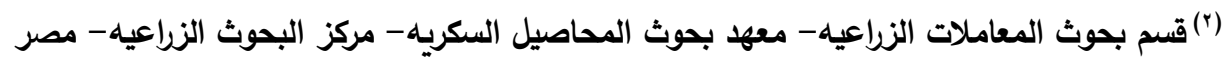

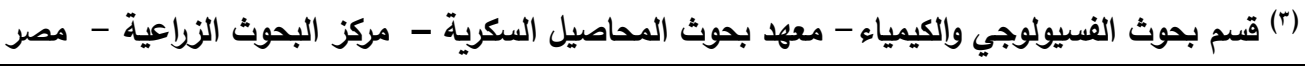

الملخص العربى

أجريت تجربة حقلية عند الكيلو V1 طريق اسكندريه- القاهره الصحراوى فى منطقة غرب النوباريه- محافظة البحيره-

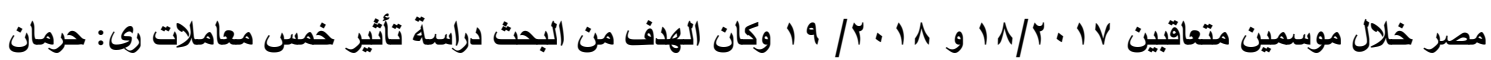

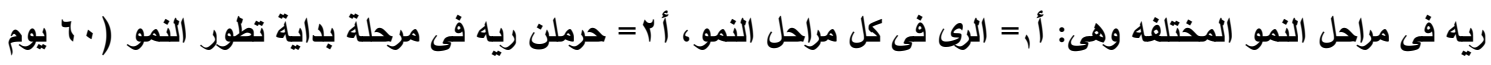

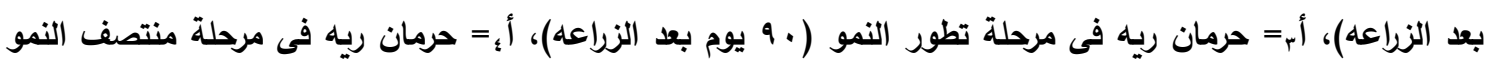

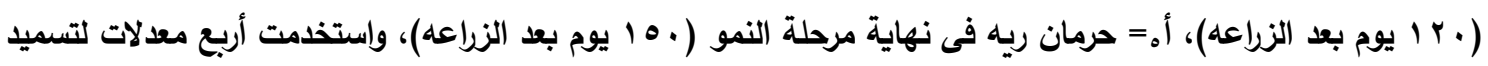

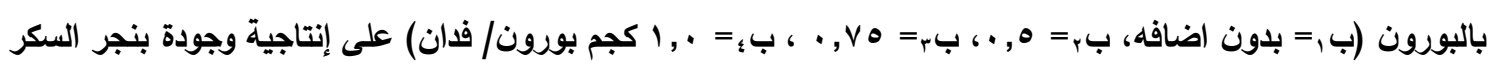

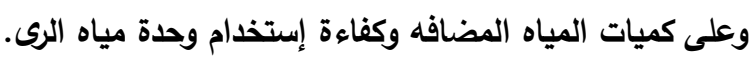

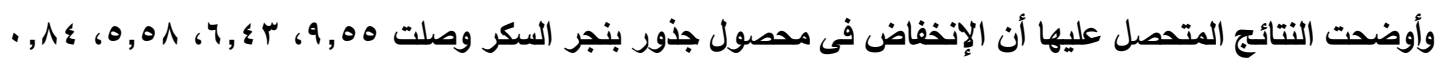

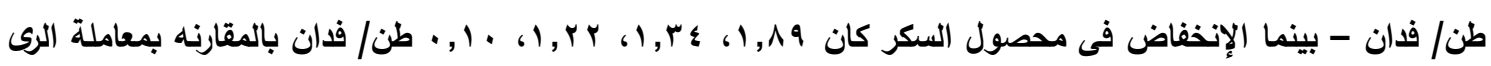

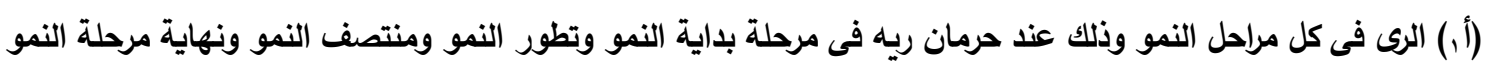
على الترتيب كمتوسط للموسمين.

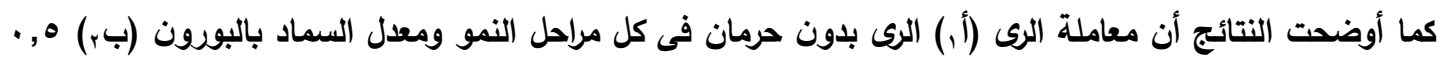

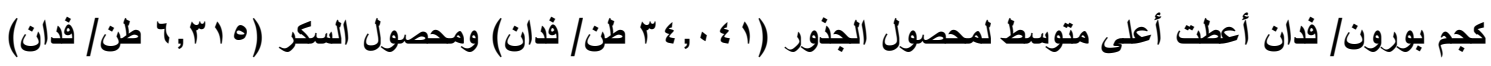

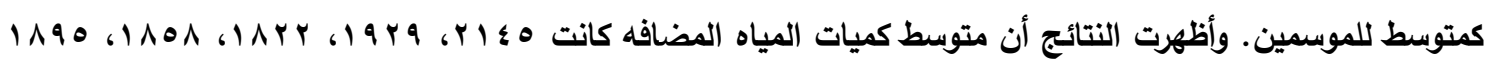

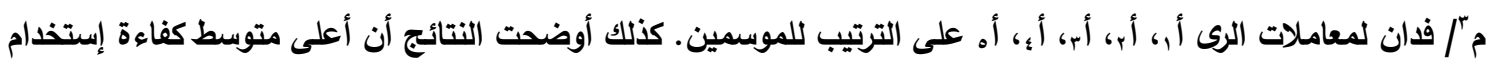

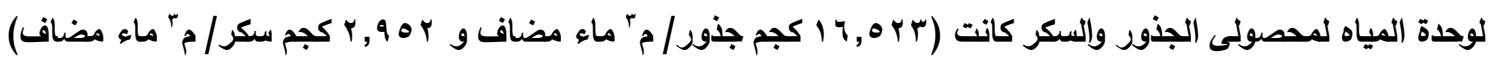

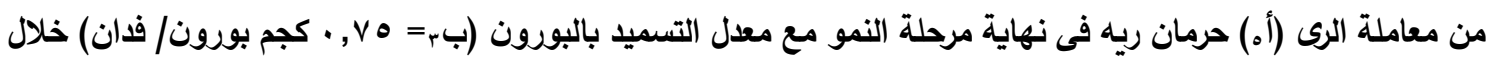
الموسمين.

لذلك نوصى فى منطقة غرب النوباريه فى حالة وفرة مياه الرى من الواجب اضافة جميع الريات دون حرمان خلال موسم

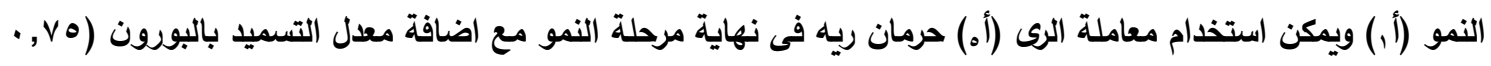

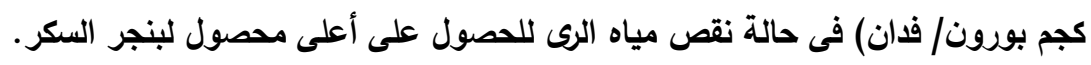

أسماء السادة المحكمين

أ.د أدمدى الحسينى خليفه مركز البحوث الزراعية- الجيزة

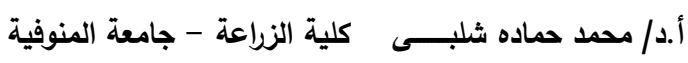


A.M. Osman, et al., 